\title{
Biomarkører ved diabetes
}

\author{
Kåre I. Birkeland ${ }^{1}$, Svein Skeie $^{2}$ og Kristian F. Hanssen ${ }^{1}$ \\ 1) Diabetesforskningssenteret Aker og Ullevål universitetssykehus, \\ Aker Universitetssykehus og Universitetet i Oslo, Oslo \\ 2) Stavanger Universitetssjukehus, Stavanger \\ Korrespondanse: Kåre I. Birkeland, Forskningssenteret, Aker universitetssykehus, 0514 Oslo \\ Telefon: 23033429 Telefax: 23033422 E-post: k.i.birkeland@medisin.uio.no
}

\begin{abstract}
SAMMENDRAG
Diabetes er en av våre vanligste folkesykdommer. Diagnosen stilles ved måling av glukose i plasma eller fullblod, enten etter 8-12 timers faste eller 2 timer etter en peroral glukosebelastningstest. De våtkjemiske målemetodene har gjennomgående god presisjon, mens tørrkjemiske metoder er for unøyaktige til diagnostiske formål og i de fleste tilfeller også til forskningsformål. Glykert hemoglobin $\left(\mathrm{HbA}_{1 c}\right)$ gjenspeiler gjennomsnittlig blodglukosekonsentrasjon de siste 6-8 uker og er en viktig parameter for å bedømme blodsukkerkontrollen hos pasienter med diabetes. Målemetodene for $\mathrm{HbA}_{1 \mathrm{c}}$ har varierende kvalitet og det er flere feilkilder det er viktig å kjenne til for å bedømme resultatene. Måling av insulin og C-peptid brukes dels til å skille mellom type 1-diabetes og type 2-diabetes, og dels for å kvantitere insulinsekresjon og insulinresistens hos personer med og uten diabetes. Ved type 1-diabetes er oftest autoantistoffer mot betacelleantigener til stede i serum, det vanligste er antistoff mot glutaminsyre decarboxylase (anti-GAD). Nylig er det utviklet målemetoder for flere avanserte glykerte endeprodukter (AGE) som kanskje kan være til hjelp i å predikere diabetiske senkomplikasjoner bedre enn måling av $\mathrm{HbA}_{1 \mathrm{c}}$ alene.
\end{abstract}

Birkeland KI, Skeie S, Hanssen KF. Biomarkers in diabetes. Nor J Epidemiol 2006; 16 (1): 15-21.

\section{ENGLISH SUMMARY}

Diabetes is one of our most common chronic diseases. It is diagnosed by measuring glucose levels in plasma, serum or full blood in the fasting state or two hours after an oral glucose tolerance test. Methods for measuring glucose that are used in larger laboratories are usually highly accurate, while the small, hand-held devices that are used by patients for home-monitoring are not accurate enough for use in diagnosing diabetes or in research. Measurement of glycated haemoglobin in full blood reflects mean glucose levels during the last 6-8 weeks. It is used to assess blood glucose levels and risk of late complications in diabetes, but not as a diagnostic tool for the disease. The methods are usually less accurate than those for measuring glucose levels. Levels of insulin and C-peptide can be measured to help differentiating between type 1-diabetes and type 2-diabetes or to assess insulin secretion and insulin resistance in subjects with or without diabetes. These substances are usually measured in the fasting state, or after a standardized stimulus, e.g. $6 \mathrm{~min}$ after $1 \mathrm{mg}$ glucagon i.v. or every $30 \mathrm{~min}$ for 2 hours after $75 \mathrm{~g}$ glucose given orally. In type 1-diabetes, auto-antibodies in serum can usually be found by the time of diagnosis, the most common is anti-GAD (glutamic acid decarboxylase). A brief review is given on the value of measuring AGE (Advanced Glycation Endproducts) as a biomarker for diabetic micro- and macrovascular complications. It is concluded that at the present time, no single AGE biomarker is available for that purpose, but progress in proteomics may change that in the near future.

\section{INNLEDNING}

Diabetes er en av våre vanligste folkesykdommer og på verdensbasis regner vi med at det i dag finnes omkring 200 millioner mennesker som har sykdommen. Utbredelsen øker i alle land vi har data for, og WHO har anslått at antallet vil nå 336 millioner i løpet av de neste 25 år. Vi mangler gode populasjonsbaserte undersøkelser av utbredelsen i Norge, men anslår at det finnes omkring 200000 med diabetes i vårt land (1). Minst like mange har sannsynligvis nedsatt glukose- toleranse, med høy risiko for å utvikle diabetes i fremtiden. Diagnosen diabetes stilles ved forhøyet blodglukose og det er internasjonal enighet om de diagnostiske kriteriene (2) (tabell 1). Grunnlaget for de diagnostiske grensene er at disse grenseverdiene representerer en risikoterskel for utvikling av de diabetesspesifikke komplikasjonene retinopati, nefropati og nevropati. Bare personer med diabetes utvikler disse komplikasjonene. Det er viktig å være klar over at samme eller annen terskel ikke finnes for utvikling av aterosklerotiske komplikasjoner og for tidlig død ved diabetes. I 
epidemiologiske studier er blodglukosenivået en klar risikofaktor også for hjerte-/og karsykdommer, men det ser ut til å være en kontinuerlig sammenheng mellom blodglukosenivået og kardiovaskulær risiko langt ned i det normale område for blodglukose (3). I tillegg til internasjonal enighet om diagnostiske grenser for diabetes, er det også enighet om at sykdommen kan inndeles i fire hovedkategorier (tabell 2). Det er imidlertid ikke alltid enkelt $\mathrm{i}$ praksis å skille mellom de ulike typene. Den hyppigste formen for diabetes er type 2-diabetes, som finnes hos $80-90 \%$ av pasientene, mens pasienter med type 1-diabetes utgjør om lag $10 \%$. De andre diabetesformene er altså relativt sjeldne. Som det fremgår av tabell 2, skyldes sykdommen absolutt insulinmangel (type 1-diabetes) eller relativ insulinmangel kombinert med redusert insulinvirkning (type 2-diabetes).

\section{GLUKOSE}

Måling av glukose i blod (fullblod, serum eller plasma) er den viktigste biomarkør ved diabetes. Grunnen er at diabetesdiagnosen knyttes til dokumentasjon av hyperglykemi. De diagnostiske kriteriene ble revidert $\mathrm{i}$ 1999 og er de samme i alle land og for alle former for diabetes. Som det fremgår av tabell 1 er det flere alternative fremgangsmåter for å stille diagnosen. Vanligvis vil man velge å måle fastende plasmaglukose. Som vist i tabell 1 kan diagnosen også stilles ved å måle glukose i plasma 2 timer etter inntak av 75 g glukose. Denne belastningstesten utfordrer fysiologien på en standardisert måte og avdekker at noen pasienter med diabetes på et tidlig stadium kan ha normalt fastende blodsukker. I tillegg kan man klassifisere en gruppe individer som har nedsatt glukosetoleranse, med plasmaglukose $2 \mathrm{t}$ etter belastning mellom 7,8 og 11,1 $\mathrm{mmol} / \mathrm{l}$. Denne gruppen har høy risiko for å utvikle diabetes (ca. 50\% i løpet av 5 år) og nesten samme risikoøkning for hjerte-/karsykdom som diabetesgruppen. Vi mangler gode, populasjonsbaserte undersøkelser fra vårt land som har undersøkt forekomsten av nedsatt glukosetoleranse og diabetes ved bruk av peroral glukosebelastningstest.
Tabell 1. Diagnostiske kriterier for diabetes mellitus.

1. Fastende (minst 8 timer) plasmaglukose $\geq 7,0 \mathrm{mmol} / 1$ (eller målt i fullblod $\geq 6,1 \mathrm{mmol} / \mathrm{l}$ ) Eller

2. Symptomer på diabetes (polyuri, polydipsi, vekttap) og tilfeldig plasmaglukose $\geq 11,1 \mathrm{mmol} / 1$ Eller

3. Totimers plasma glukose $\geq 11,1 \mathrm{mmol} / 1$ etter en peroral glukosetoleransetest (OGTT med 75g glukose løst i vann).

Diagnosen bør alltid bekreftes med en måling på en annen dag, fastende, tilfeldig eller etter glukosebelastning (OGTT). Dersom fastende eller tilfeldig plasma glukose ikke er diagnostisk, benyttes totimersverdien etter OGTT.

Måling av glukose benyttes også i utstrakt grad ved screeningundersøkelser for diabetes. Denne situasjonen er spesiell, fordi hensikten er å identifisere asymptomatiske individer som har økt sannsynlighet for å ha diagnosen. En positiv screeningtest må etterfølges av diagnostisk testing før endelig diagnose kan etableres. Her omtales ikke screening ytterligere men det vises til relevant litteratur (4).

\section{Feilkilder ved måling av glukose i blod}

Siden diabetesdiagnosen hviler på analyse av glukose alene er det avgjørende at man kan stole på resultatet av analysen. Det er derfor viktig å være klar over mulige feilkilder knyttet til analysen for å unngå feildiagnoser. De diagnostiske kriteriene tar også hensyn til dette ettersom det kreves repetert testing hos asymptomatiske individer for $̊$ a redusere muligheten for feildiagnostikk. De diagnostiske kriteriene gir ikke spesifikke anbefalinger når det gjelder valg av analysemetode for glukose.

Pre-analytiske feil reduseres betydelig ved at kriteriene anbefaler fastende prøver. Analyse i plasma (glass med Na fluorid/heparin) (eller serum) anbefales, sentrifugering og utskilling av plasma bør skje innen 30-60 minutter og plasma bør sendes til et laboratorium for våtkjemisk analyse $(5,6)$. Fullblod må ikke sendes inn for analyse. Årsaken er først og fremst at glykolysen i de røde blodcellene forbruker glukose

Tabell 2. Klassifikasjon av diabetes i ulike typer.

1. Type 1 diabetes. Skyldes vanligvis autoimmun destruksjon av de insulinproduserende cellene i bukspyttkjertelen.

2. Type 2 diabetes. Skyldes en kombinasjon av insulinresistens og relativ insulinmangel.

3. Andre spesielle typer. Gruppen omfatter enkelte sjeldne arvelige former for diabetes, for eksempel
a. MODY (Maturity onset diabetes of the young) hvor vi i dag kjenner minst seks ulike genetiske mutasjoner
b. Mutasjoner i insulinreseptorgenet
c. Diabetes ved pankreassykdommer
d. Diabetes ved andre endokrine sykdommer
e. Andre sjeldne former

4. Diabetes i svangerskapet 
etter at blodet er tappet. Reflektometere som benyttes til glukosemålinger av pasientene selv og i allmennpraksis, har ikke god nok presisjon til å benyttes diagnostisk. I spesielle tilfeller, for eksempel ved undersøkelse av et stort antall individer under feltforhold, har slike apparater vært brukt til forskningsformål. Også ved analyse av fullblod med mindre laboratorieinstrumenter som benyttes i allmennpraksis (for eksempel Hemocue) er en bekreftende analyse ved et laboratorium med veletablerte rutiner for kvalitetskontroll ønskelig. Selv om nyere instrumenter har god analytisk kvalitet med upresishet på $<2-3 \%$, vil den høye biologiske (intra-individuelle) variasjonskoeffisient (CV) på 5-7\% kunne gi klassifikasjonsfeil hos enkeltindivider. En analytisk upresishet $\leq 3,3 \%$ og en bias $\leq 2,5 \%$ anbefales (5). Når man tar hensyn til feilkildene bør et tilfeldig (ikke-fastende) plasmaglukose-resultat være $<5,5 \mathrm{mmol} / \mathrm{l}$ før en kan være rimelig sikker på at det undersøkte individ ikke har diabetes $(6,7)$.

\section{GLYKERT HEMOGLOBIN $\left(\mathrm{HbA}_{1 \mathrm{c}}\right)$}

Glukose bindes til blodfargestoffet hemoglobin hos alle mennesker. Flere HbA-fraksjoner binder glukose i varierende grad, c-fraksjonen er den dominerende $(80 \%)$ og den som bestemmes $\mathrm{i} \mathrm{HbA}_{1 \mathrm{c}}$-analysen vi bruker i dag. $\mathrm{HbA}_{1 \mathrm{c}}$-nivået vil være direkte proporsjonalt med den konsentrasjon av glukose som erytrocyttene utsettes for. Med vanlig erytrocyttlevetid omkring 120 dager vil $\mathrm{HbA}_{1 \mathrm{c}}$ resultatet gi et bilde av gjennomsnittlig glukosekonsentrasjon de siste 6-8 uker, hvor siste del av perioden er mest betydningsfull. Personer med diabetes og gjennomsnittlig forhøyet glukosenivå vil dermed få et forhøyet $\mathrm{HbA}_{1 \mathrm{c}}$-nivå. Resultatene uttrykkes i prosent av hemoglobin-nivået. Selve bindingen til ß-kjeden i hemoglobinet er non-enzymatisk og irreversibel. Det dannes et stabilt Amadori-produkt som er det vi måler i $\mathrm{HbA}_{1 \mathrm{c}}$-analysen.

$$
\text { Hemoglobin }+ \text { glukose } \leftrightarrow \text { Schiff base } \rightarrow \mathrm{HbA}_{1 \mathrm{c}}
$$

Måling av $\mathrm{HbA}_{1 \mathrm{c}}$ er i dag den viktigste analysen for å evaluere glukose-nivået over tid og for å kunne bedømme risikoen for å utvikle senkomplikasjoner relatert til forhøyet blodglukosenivå (4,7-9). Behandlingsretningslinjer anbefaler $\mathrm{i}$ dag å tilstrebe et $\mathrm{HbA}_{1 \mathrm{c}}$-nivå under $6,5-7,5 \%$, litt avhengig av hvor anbefalingene kommer fra og metodiske analyseforskjeller $(4,5,7)$. Det følger imidlertid av det som er nevnt innledningsvis om bakgrunnen for den diagnostiske blodglukosegrensen at risiko for mikrovaskulære senkomplikasjoner alltid vil være til stede så lenge $\mathrm{HbA}_{1 \mathrm{c}}$-verdien er høyere enn normalområdet. Måling av glykert hemoglobin anbefales ikke i dag brukt for å stille diagnosen diabetes. Det er likevel selvsagt slik at forhøyet $\mathrm{HbA}_{1 \mathrm{c}}$ øker sjansen for at en person har diabetes. I fremtiden kan muligens standardisering av analysen og bedre analysekvalitet gjøre det mulig å bruke denne i diagnostisk sammenheng.
Standardisering av $\mathrm{HbA}_{1 \mathrm{c}}$-metodene har lenge vært et problem, fordi man har benyttet varierende analysemetoder ved forskjellige laboratorier og i forskjellige land. Metoden som ble brukt til bestemmelse av $\mathrm{HbA}_{1 \mathrm{c}}$ i DCCT-studien har lenge blitt oppfattet som en referansemetode $(8)$, men man har nå kommet til enighet om innføring av en ny internasjonal referansemetode (10). Denne referansemetoden vil kunne gjøre det lettere for laboratoriene å oppnå tilfredsstillende analysekvalitet, redusere variasjonen mellom laboratorier og gi klinikere et bedre grunnlag for å monitorere blodsukkernivået over tid. Samarbeidet omkring referansemetoden tar også sikte på å innføre en ny rapporteringsskala for $\mathrm{HbA}_{1 \mathrm{c}}$ slik at det tall som oppgis som analyseresultat også reflekterer gjennomsnittlig plasma-glukosenivå. Fremtiden vil vise om $\mathrm{HbA}_{1 \mathrm{c}^{-}}$ analysen deretter kan få en plass også innenfor diabetes-diagnostikken.

\section{Feilkilder ved måling av $\mathrm{Hb}_{1 c}$}

Siden analysen måler glykert hemoglobin i erytrocyttene vil alle tilstander som forkorter de røde blodlegemers levetid kunne føre til falskt lave resultater (for eksempel hemolytisk anemi, blødningsanemi). Høye triglyseridverdier, høyt alkoholforbruk og bruk av salicylater kan gi falskt forhøyet resultat. Forskjellige hemoglobinopatier kan også forstyrre, men disse tilstandene er sjeldne i Norge. Noen metoder påvirkes av høyt nivå av urinstoff (ved nyresvikt). Generelt anbefales laboratoriene å benytte metoder som har en CV mellom laboratorier $<5 \%$ og innen laboratoriet $<3 \%$. I dag er variasjonen mellom laboratorier ofte større og dette vanskeliggjør direkte sammenligning av resultater både for enkeltpasienter og $\mathrm{i}$ forskningssammenheng.

\section{INSULIN OG C-PEPTID}

Måling av insulin og C-peptid har ingen plass i diagnostikk av diabetes, men kan hjelpe ved differensieringen mellom ulike typer diabetes og ved nærmere karakterisering av sykdommen. Insulin og C-peptid utskilles i ekvimolare mengder fra de insulinproduserende cellene i pankreas til vena porta. De når derfor leveren først, og fordi dette organet er et viktig målorgan for insulin, bindes $50-80 \%$ til reseptorer på hepatocyttene, internaliseres i cellene, degraderes og kommer ikke ut $\mathrm{i}$ den systemiske sirkulasjonen. Vi regner med at C-peptid stort sett passerer leveren uforandret og det utskilles via nyrene. Halveringstiden i blodet er 3-5 minutter for insulin og 20-30 minutter for C-peptid. Insulin utskilles i pulser med få minutters mellomrom og nivået stiger dessuten sterkt i forbindelse med måltid. C-peptidutskillelsen resulterer ikke i den samme pulsatilitet, men stiger i likhet med insulin også kraftig etter måltider. Ved vurdering av insulin og C-peptid målinger er det derfor avgjørende viktig å vite når prøven er tatt $\mathrm{i}$ forhold til siste inntak av fødemidler. Den 
viktigste fysiologiske regulator av insulinsekresjonen er glukosenivået, gjennom en positiv tilbakekoblingssløyfe: En liten økning i blodglukosenivået fører umiddelbart til økning av insulinsekresjonen, så sant betacellen er i stand til det. Det betyr at redusert insulinvirkning i lever og perifere vev, som fører til forsinket glukoseopptak perifert, økt glukoseproduksjon fra lever og lett økning i blodglukosenivået, vil ledsages av et økt nivå av insulin og C-peptid.

Måling av insulin og C-peptid foretas i praksis vanligvis i følgende standardiserte situasjoner:

1. Prøver tatt etter 8-12 timers faste. Dette er den best standardiserte og reproduserbare situasjon og anbefales i de fleste tilfeller. Den gir i det vesentlige informasjon om basal insulinproduksjon og kan brukes til å diagnostisere komplett insulinmangel (type 1 diabetes). Fastende C-peptidnivå vil ved type 1 diabetes vanligvis være $<300 \mathrm{pmol} / 1$. Dersom betacellen er (noenlunde) normal, vil fastende insulin og C-peptidnivå også gjenspeile insulinresistens, på grunn av den positive tilbakekoblingssløyfen som er omtalt over. Et fastende insulin- eller Cpeptidnivå over laboratoriets øvre referansegrense, samtidig med at blodsukkeret er normalt eller forhøyet, vil vanligvis bety insulinresistens. Ulempe: Hvis betacellen ikke fungerer normalt, vil den positive tilbakekoblingssløyfen ikke være normal og fastende insulin- og C-peptidnivå vil være dårlige mål på insulinresistens.

2. Glukagonstimulert C-peptid. Man måler C-peptid før og 6 minutter etter $1 \mathrm{mg}$ glukagon i.v. Det måler "betacellereserven", og vanligvis finnes en stimulert verdi $<600 \mathrm{pmol} / 1$ ved type 1 diabetes. Ulempe: Intravenøs glukagonstimulering representerer en ufysiologisk situasjon og man er usikker på den kliniske betydning av resultatet. Undersøkelsen kan en sjelden gang gi bivirkninger $i$ form av kvalme/oppkast.

3. Måltidstimulerte verdier. Insulinnivået er vanligvis maksimalt 60-120 min etter måltid, C-peptidnivået 90-180 min etter måltid. Ved å ta prøve ved disse tidspunktene får vi et uttrykk for insulinproduksjonen $i$ en vanlig fysiologisk situasjon. Det kan for eksempel brukes for å følge enkeltindivider over tid med repeterte målinger for å vurdere om en pasient med type 2-diabetes utvikler så uttalt insulinmangel at insulinbehandling er nødvendig, når blodsukkerkontrollen ikke er tilfredsstillende. Ulempe: metoden er lite standardisert og resultatet avhenger i stor grad av måltidets sammensetning, absorbsjonshastighet fra tarmen osv.

4. Peroral- eller intravenøs glukosebelastningstest (OGTT og IVGTT) med repeterte målinger. Testene kan brukes til å måle glukosestimulerte insulinverdier og har en plass i mer nøyaktig vurdering av insulinsekresjon og insulinresistens enn det som fremkommer fra enkeltprøver. Det finnes mange ulike protokoller for slike tester, de fleste fremhever betydningen av et adekvat karbohydratinntak de tre siste dagene før testen foretas $(>150 \mathrm{~g} / \mathrm{d})$. OGTT: Vanligst er det å bruke $75 \mathrm{~g}$ anhydrert glukose oppløst i vann (evt. tilsatt noen dråper sitron) som drikkes i løpet av få minutter. Dersom man er interessert i å vurdere insulinsekresjonen, må serum til måling av insulin tas minst hvert 30. minutt. IVGTT: Vanligst er det å gi 0,3-0,5 g glukose per kg kroppsvekt i løpet av 1 min i.v. og ta hyppige prøver i 15 180 minutter, avhengig av problemstilling.

\section{Feilkilder ved måling av insulin og C-peptid}

Det viktigste er betydningen av å standardisere prøvetakningen i forhold til måltid. Substansene måles med immunoassay og metodene og referanseverdiene varierer mellom laboratoriene. C-peptidverdiene oppgis vanligvis som nmol/1 eller pmol/1 (11). Metodene for insulinmåling har varierende spesifisitet ved at eldre metoder i stor grad medbestemmer biologisk inaktivt proinsulin og spaltningsprodukter av proinsulin. De måler derfor høyere verdier enn hva som er reell insulinkonsentrasjon i blodet. Nyere metoder medbestemmer proinsulin og spaltningsprodukter i liten grad (11). Flere av metodene har en så høy nedre målegrense at fastende verdier hos friske ikke kan måles. Det finnes imidlertid supersensitive assays med meget lav nedre målegrense. Insulinverdiene oppgis enten som $\mathrm{pmol} / 1$, som er vanligst i Norge, eller som mU/1 (evt. $\square \mathrm{U} / \mathrm{ml}$ ) som er vanligst i USA. Omregningsfaktoren er 6 , dvs. at $1 \mathrm{mU} / 1=6 \mathrm{pmol} / \mathrm{l})$. Måling av insulin hos diabetespasienter under behandling med humant insulin vil medbestemme eksogent human-insulin, men vanligvis ikke insulinanaloger, dog avhengig av spesifisiteten $i$ det enkelte insulinassay. Dersom det finnes insulinantistoffer i blodet (vanligvis som følge av insulinbehandling) vil de interferere med analysen og måleresultatet blir feil om ikke det tas spesielt hensyn til dette ved prøvetaking og analyse. Serum til insulinmåling i vanlig klinisk bruk sendes normalt ufrosset til laboratoriet. Til forskningsbruk og når det er spesielt høye krav til nøyaktighet anbefales det å fryse prøvene umiddelbart etter at serum er separert og sende serum frosset, ettersom man har vist at insulinnivået reduseres med ca. $30 \%$ etter fire dager ved romtemperatur (11).

\section{INDEKSER FOR VURDERING AV INSULIN- RESISTENS OG INSULINSEKRESJON}

I epidemiologisk og klinisk forskning ønsker man ofte å måle insulinresistens og insulinsekresjon som er de grunnleggende patogentiske forstyrrelsene ved diabetes. Referansemetodene for å estimere dette er euglykemisk og hyperglykemisk glukose clamp (12) eller "Bergmans minimal model" (13). Dette er kompliserte, kostbare og arbeidskrevende undersøkelser som ikke er egnet for klinisk bruk og heller ikke for masseundersøkelser. Mange har derfor søkt etter surrogater 
som er rimeligere og enklere, og det finnes en rekke slike. Her skal bare kort omtales en algoritme som er avledet fra måling av fastende glukose og insulin. Metoden kalles Homeostasis Model Assessment (HOMA) og ble første gang beskrevet av Matthews og medarbeidere i 1985 (14). Den er senere modifisert flere ganger og brukes svært mye. De enkleste formlene for HOMA-S (insulinsensitivitet) og HOMA-B (betacellefunksjon) er angitt i tabell 3. Det finnes også en mer komplisert algoritme som fritt kan lastes ned fra internett (15). Det finnes også flere indekser som tar utgangspunkt i måling av s-insulin og p-glukose under en glukosebelastningstest. De er gjennomgående bedre enn indeksene som bare bruker fastende verdier, i hvert fall når det gjelder å vurdere insulinsekresjonen. Noen av de mest brukte er "insulinsensitivitetsindeks" (Matsuda indeks) (16) for vurdering av insulinsensitivitet og "insulinogenic index "eller "disposition index" for vurdering av insulinsekresjon (17) (tabell 3).

\section{Autohntistoffer}

Ved debut av type 1-diabetes vil 70-90\% av pasientene ha påvisbare autoantistoffer mot betacelleantigener $\mathrm{i}$ serum. Vanligst er antistoff mot glutaminsyre decarboxylase (anti-GAD), men mange pasienter vil også ha øycelleantistoffer (IAA, islet cell antibodies), antistoff mot øycelleantigen-2 (IA-2 antistoffer) eller autoantistoffer mot insulin (insulinantistoffer). Måling av slike autoantistoffer kan hjelpe i klassifiseringen av diabetessykdommen, men sensitiviteten er ikke $100 \%$. Man regner imidlertid at spesifisiteten er absolutt, slik at alle pasienter med diabetes som får påvist autoantistoffer i serum regnes for å ha type 1-diabetes. Noen voksne pasienter som initialt har et sykdomsbilde som likner type 2-diabetes (langsom debut, moderat hyperglykemi, god initial respons på livsstilsbehandling og evt. tabletter) viser seg å ha påvisbare autoantistoffer $\mathrm{i}$ serum. Tidligere ble denne diabetesformen kalt LADA (Late-onset autoimmune diabetes in the adult). Man er nå enige om å klassifisere dette som type 1-diabetes. Måling av autoantistoffer kan også benyttes for å identifisere individer med høy risiko for å utvikle type 1-diabetes, ettersom antistoffene vanligvis kan påvises i kortere eller lengre tid før sykdommen debuterer. Anti-GAD antistoff påvises hyppigst, men generelt er risikoen for å utvikle type-1 diabetes høyere dess flere antistoffer som er til stede. Slike målinger kan være aktuelle i forskningsprosjekter, for eksempel hvor man vil identifisere høyrisikoindivider $\mathrm{i}$ forbindelse med utprøving av forebyggende behandling, men har ingen plass i klinisk bruk.

\section{GLYKERTE ENDEPRODUKTER}

Selv om det er veldokumentert at gjennomsnittlig høyt blodglukosenivå målt som høy $\mathrm{HbA}_{1 \mathrm{c}}$ gjennom mange år er den viktigste faktor for progresjon av mikro- og makrovaskulære komplikasjoner ved både type 1- og type 2-diabetes $(8,9)$ er mekanismen(e) for hyperglykemiens skadelige virkning ukjent. Det er i øyeblikket fire hovedarbeidshypoteser for den skadelige virkningen av hyperglykemi (18):

- Økt aktivitet i polyol-reaksjonsveien

- Økt aktivitet i hexosamin-reaksjonsveien

- Aktivering av protein kinase C

- Dannelse av avanserte glykerte endeprodukter (AGE)

Disse fire mekanismer virker tildels sammen.

$\mathrm{HbA}_{1 \mathrm{c}}$ er omtalt tidligere, og er meget godt korrelert til aritmetrisk gjennomsnitt av blodglukosenivået. Det har likevel en del svakheter som biomarkør, og

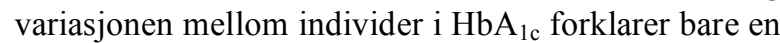
viss andel (30-50\% ?) av variasjonen i progresjonen av mikrovaskulære komplikasjoner. Videre er $\mathrm{HbA}_{1 \mathrm{c}}$ så vidt vi vet $\mathrm{i}$ dag ikke involvert $\mathrm{i}$ patogenesen for senkomplikasjoner og det reflekterer ikke korttidssvinginger i glukosekonsentrasjonen. Det må dessuten måles i erytrocytter som er vanskeligere å lagre enn plasma eller serum. Det er derfor behov for andre biomarkører som kan predikere diabetiske senkomplikasjoner. Det er nærliggende å vurdere AGE, som kan måles i serum og som sannsynligvis er knyttet til patogenesen for senkomplikasjoner.

Tabell 3. Noen indekser for beregning av insulinsensitivitet og insulinsekresjon (referanseområder hentet fra 11).

HOMA-IR (insulinresistens) = S-insulin $(\mathrm{pmol} / \mathrm{l}) \mathrm{x}$ glukose $(\mathrm{mmol} / \mathrm{l}) / 135$

Referanseområde for individer med normal glukosetoleranse: 1,1-10,7

HOMA-BCF $($ betacellefunksjon $)=($ S-insulin $(\mathrm{pmol} / \mathrm{l}) \times 3,33) /($ glukose $(\mathrm{mmol} / \mathrm{l})-3,5)$

Referanseområde for individer med normal glukosetoleranse: $83-525$

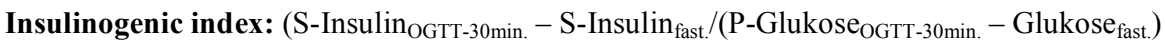

Disposition index: Insulinogenic index/HOMA-IR 
Dannelse av AGE er en vanlig post-translasjonell modifisering av proteiner også hos friske individer og kan foregå via mange mekanismer (19). Vanligvis foregår AGE-dannelsen ved ikke-enzymatisk kondensasjon mellom sukkerarter eller intermediærprodukter $\mathrm{i}$ sukkeromsetningen og endestående aminosyrer (særlig lysin og arginin) på proteiner. Dette fører til en rekke modifikasjoner (ca. 50 er beskrevet) og mange av disse er assosiert med diabetiske senkomplikasjoner. Det er interessant at mange av dem ikke er assosiert med $\mathrm{HbA}_{1 \mathrm{c}}$.

\section{Serummålinger}

Serummålinger av AGE kan gjøres ved immunoassay, HPLC eller gasskromatografi-massespektrometri (GC$\mathrm{MS}$ ). Dette er alle kompliserte teknikker som har sine svakheter og styrker. Det er funnet assosiasjoner i tverrsnittsundersøkelser mellom utbredelsen av mikrovaskulære senkomplikasjoner og serummålinger av AGE-modifiserte proteiner. Det gjelder både for "total" AGE (20), carboxymethyllysine (CML), pentosidine, furosine og hydroimidazolone (21). Det er imidlertid fortsatt usikkert hvilken av disse (om noen) som er patogenetisk knyttet til senkomplikasjoner (22).

Det er viktig å være klar over at redusert nyrefunksjon uavhengig av årsak, fører til en økning av de fleste AGE-produkter i serum. Det er få prospektive studier publisert som har undersøkt hvordan serummålinger av forskjellige AGE-produkter kan forutsi progresjonen av senkomplikasjoner. En undersøkelse viste at måling av den fri fraksjonen av plasmapentosidine predikerte forverrelse av nyrefunksjonen hos pasienter med diabetisk nyresykdom.

\section{Måling $\boldsymbol{i}$ hud}

Vi har lenge kjent til at noen AGE-produkter har autofluorescens dvs. at de utsender lys når de blir belyst. Dette kan måles enten i hudbiopsier eller som måling av autofluorescens i hud ved hjelp av apparat som settes på huden (AGEreaderTM, DiagnOptics, BV, Groningen, Nederland). Det beste samsvar mellom AGE-måling og progresjon av senkomplikasjoner er vist ved måling av glykert lysin (furosine, pentosidine) og CML i hudbiopsier, enten med kjemisk måling eller med måling av autofluorescens. Disse målingene predikerte utviklingen av senkomplikasjoner bedre enn $\mathrm{HbA}_{1 \mathrm{c}}$ (23). Undersøkelser viser assosiasjon mellom autofluorescens og alle mikrovaskulære komplikasjoner (24). Instrumentet er nå kommersielt tilgjengelig. Serumnivået av "total AGE" har vist signifikant assosiasjon med utbredelsen av hjerte-/og karsykdommer ved type 2-diabetes (25). Fluorescensmåling i hudbiopsier er assosiert med hjerte-/kar-sykdom ved type 1 diabetes.

\section{KONKLUSJON}

AGE-målinger i serum er sterkt assosiert til både mikro- og makrovaskulære komplikasjoner ved diabetes. Det er ikke kjent hvilken av de forskjellige AGEmodifikasjonene av protein som er viktigst for patogenesen ved senkomplikasjoner. Målemetodene som brukes er kompliserte og måler til dels forskjellige modifikasjoner av proteiner. Det arbeides videre med nye proteinkjemiske metoder av typen MALDI-TOFMS som muligens kan gjøre den kjemiske identifikasjon av hvilke(n) AGE som er viktigst lettere å gjennomføre. Måling av AGE i hud enten ved hudbiopsi eller autofluorescens er en meget lovende metode, delvis fordi en da får den kumulative opphoping av AGE i kollagen som uttrykker en langtidsvirkning over mange år, som jo er karakteristisk forløp ved utvikling av diabetiske senkomplikasjoner. AGE-målinger er foreløpig forskningsverktøy, men ventes å bli tatt i bruk i klinisk pasientbehandling innen få år.

Den perfekte biomarkør for diabetiske senkomplikasjoner er ennå ikke funnet, men fra vårt ståsted kan det $\mathrm{i}$ dag se ut til å være en kombinasjon av $\mathrm{HbA}_{1 \mathrm{c}}$ og flere AGE-produkter.

\section{REFERANSER}

1. Stene LC, Midthjell K, Jenum AK, et al. Prevalence of diabetes mellitus in Norway. Tidsskr Nor Laegeforen 2004; 124: 1511-1514.

2. Definition, diagnosis and classification of diabetes mellitus and its complications. Report of a WHO Consultation, Geneva: WHO WHO/NCD/NCS99.2, 1999.

3. Glucose tolerance and mortality: comparison of WHO and American Diabetes Association diagnostic criteria. The DECODE study group. European Diabetes Epidemiology Group. Diabetes Epidemiology: Collaborative analysis Of Diagnostic criteria in Europe. Lancet 1999; 354: 617-621.

4. American Diabetes Association: Clinical practice recommendations 2005. Diabetes Care 2005; 28 (suppl): S4-S36.

5. Sacks DB, Bruns DE, Goldstein DE, et al. Guidelines and recommendations for laboratory analysis in the diagnosis and management of diabetes mellitus. Clin Chem 2002; 48: 436-472.

6. Stahl M, Jorgensen LG, Hyltoft Petersen P, et al. Optimization of preanalytical conditions and analysis of plasma glucose. 1. Impact of the new WHO and ADA recommendations on diagnosis of diabetes mellitus. Scand J Clin Lab Invest 2001; 61: 169-179. 
7. Handlingsprogram for diabetes i almenpraksis. http://www.nsamdiabetes.no. Adressert 5.12.05.

8. The effect of intensive treatment of diabetes on the development and progression of long-term complications in insulin-dependent diabetes mellitus. The Diabetes Control and Complications Trial Research Group. $N$ Engl J Med 1993; 329: 977-986.

9. United Kingdom Prospective Diabetes Study Group. Intensive blood-glucose control with sulphonylureas or insulin compared with conventional treatment and risk of complications in patients with type 2 diabetes (UKPDS 33). Lancet 1998; 352: 837-853.

10. Sacks DB. Global harmonization of hemoglobin A1c. Clin Chem 2005; 51: 681-683.

11. Hormonlaboratoriets analysebok. http://www.akersykehus.no/Hormonlab/Analysehandbok. Adressert 5.12.05.

12. DeFronzo RA, Tobin JD, Andres R. Glucose clamp technique: a method for quantifying insulin secretion and resistance. Am J Physiol 1979; 237: E214-E223.

13. Bergman RN, Finegood DT, Ader M. Assessment of insulin sensitivity in vivo. Endocr Rev 1985; 6: 45-86.

14. Matthews DR, Hosker JP, Rudenski AS, et al. Homeostasis model assessment: insulin resistance and beta-cell function from fasting plasma glucose and insulin concentrations in man. Diabetologia 1985; 28: 412-419.

15. Homeostasis model assessment calculator. http://www.dtu.ox.ac.uk/index.html?maindoc=/homa/. Adressert 5.12 .05 .

16. Matsuda M, DeFronzo RA. Insulin sensitivity indices obtained from oral glucose tolerance testing. Comparison with the euglycemic insulin clamp. Diabetes Care 1999; 22: 1462-70.

17. Lyssenko V, Almgren P, Anevski D, Perfekt R, et al. Predictors and longitudinal changes in insulin sensitivity and secretion preceding onset of type 2 diabetes. Diabetes 2005; 54: 166-174.

18. Brownlee M. Biochemistry and molecular cell biology of diabetic complications. Nature 2001; 414: 813-820.

19. Fraser D, Hanssen K. Making sense of advanced glycation endproducts and their relevance to diabetic complications. International Diabetes Monitor 2005; 17: 1-7.

20. Berg TJ, Bangstad HJ, Torjesen PA, et al. Advanced glycation end products in serum predict changes in the kidney morphology of patients with insulin-dependent diabetes mellitus. Metabolism 1997; 46: 661-665.

21. Forsmark D, Torjesen P, Kilhovd B, et al. Increased serum levels of the specific advanced glycation end product methylglyoxal-derived hydroimidazolone are associated with retinopathy in patients with type 2 diabetes mellitus. Metabolism 2006; 55: 232-236.

22. Monnier VM, Sell DR, Genuth S. Glycation products as markers and predictors of the progression of diabetic complications. Ann N Y Acad Sci 2005; 1043: 567-581.

23. Meerwaldt R, Links T, Graaff R, et al. Simple non-invasive measurement of skin autofluorescence. Ann NY Acad Sci 2005; 1043: 290-298.

24. Genuth S, Sun W, Cleary P, et al. Glycation and carboxymethyllysine levels in skin collagen predict the risk of future 10-year progression of diabetic retinopathy and nephropathy in the diabetes control and complications trial and epidemiology of diabetes interventions and complications participants with type 1 diabetes. Diabetes 2005; 54: 3103-3111.

25. Kilhovd BK, Berg TJ, Birkeland KI, et al. Serum levels of advanced glycation end products are increased in patients with type 2 diabetes and coronary heart disease. Diabetes Care 1999; 22: 1543-1548. 